\title{
THERMAL STABILITY OF THE Cu-CeO INTERFACE ON SILICA AND ALUMINA, AND ITS RELATION WITH ACTIVITY IN THE OXIDATION REACTION OF CO AND THE DECOMPOSITION OF $\mathrm{N}_{2} \mathrm{O}$
}

\author{
PABLO ALVAREZ(I), GONZALO AGUILA ${ }^{(2)}$, SICHEM GUERRERO(3) AND PAULO ARAYA ${ }^{(1) *}$
}

\author{
(1)Departamento de Ingeniería Química, Biotecnología y Materiales, Facultad de Ciencias Físicas y Matemáticas, \\ Universidad de Chile, Beauchef 851, Santiago, Chile. \\ (2) Departamento de Ciencias de la Ingeniería, Facultad de Ingeniería, Universidad Andres Bello, Antonio Varas 880, Providencia, Santiago, Chile. \\ ${ }^{(3)}$ Facultad de Ingeniería y Ciencias Aplicadas, Universidad de los Andes, Monseñor Álvaro del Portillo 12455, Las Condes, Santiago, Chile.
}

\section{ABSTRACT}

The effect of the support on the formation of the $\mathrm{Cu}-\mathrm{CeO}_{2}$ interface and its thermal stability after calcination at 500,700 and $900{ }^{\circ} \mathrm{C}$ is studied. The supports used are $\mathrm{SiO}_{2}$, because of its inert character, and $\mathrm{Al}_{2} \mathrm{O}_{3}$, because it can interact with the $\mathrm{Cu}$ and Ce species on the surface. The catalysts were characterized by BET, XRD, UV-vis DRS, and TPR with $\mathrm{H}_{2}$. The catalytic activity in the $\mathrm{CO}$ oxidation reactions with $\mathrm{O}_{2}$ at low temperature and the decomposition of $\mathrm{N}_{2} \mathrm{O}$ were selected to visualize the effect of temperature on the concentration of $\mathrm{Cu}-\mathrm{CeO}$ interfacial sites. The results show that at a calcination temperature of $500{ }^{\circ} \mathrm{C}$ the formation of the $\mathrm{Cu}-\mathrm{CeO}_{2}$ interface is favored over the $\mathrm{SiO}_{2}$ support. However, the stability of the $\mathrm{Cu}-\mathrm{CeO}_{2}$ interface on $\mathrm{SiO}_{2}$ is much lower than on $\mathrm{Al}_{2} \mathrm{O}_{3}$, causing a substantial decrease of the interfacial sites calcining at $700{ }^{\circ} \mathrm{C}$, and segregation of the $\mathrm{Cu}$ and Ce species on the surface of the silica, with complete loss of the catalytic activity in both reactions when calcining at $900^{\circ} \mathrm{C}$. In contrast, on alumina the $\mathrm{Cu}-\mathrm{CeO}_{2}$ interface is more stable and presents a significant catalytic activity in both reactions, even when calcining at $900{ }^{\circ} \mathrm{C}$. The characterization results show that the sintering process of $\mathrm{Cu}$ species and $\mathrm{CeO}{ }_{2}$ particles is less on the alumina support due to the greater interaction of the $\mathrm{Cu}$ and $\mathrm{Ce}$ with this support.

KEYWORDS: $\mathrm{Cu}, \mathrm{Ce}$, silica, alumina, $\mathrm{CO}$ oxidation, $\mathrm{N}_{2} \mathrm{O}$ decomposition.

\section{1.- INTRODUCTION}

The $\mathrm{CuO}-\mathrm{CeO}_{2}$ system has shown excellent catalytic properties for a series of reactions including the oxidation of $\mathrm{CO}$ with $\mathrm{O}_{2}[1,2]$ and the WGS reaction between $\mathrm{CO}$ and $\mathrm{H}_{2} \mathrm{O}$, which produces $\mathrm{H}_{2}$ and $\mathrm{CO}_{2}$ [3]. Furthermore, in the oxidation of $\mathrm{CO}$ with $\mathrm{O}_{2}$, the $\mathrm{Cu}-\mathrm{CeO}_{2}$ system has proven to be even more active than $\mathrm{Pt}$ supported catalysts [4]. The $\mathrm{CuO}-\mathrm{CeO}$, system is also very active and selective in its preferential oxidation of $\mathrm{CO}$ with $\mathrm{O}_{2}$ in the presence of $\mathrm{H}_{2}$ (PROX reaction), making it a very attractive system to generate $\mathrm{H}_{2}$ with the high purity required by fuel cells [5].

In both reactions, the $\mathrm{CO}$ oxidation and the WGS, the $\mathrm{Cu}-\mathrm{CeO}_{2}$ interface sites play an important role in the activity of the catalyst. The facility of the Ce (III) - Ce (IV) redox cycle and the high mobility of oxygen in the crystal structure of $\mathrm{CeO}_{2}$ are two important properties of $\mathrm{CeO}_{2}$ [6]. As a result, this oxide is capable of reversibly "adsorbing" oxygen. The high activity of the $\mathrm{CuO}-\mathrm{CeO}_{2}$ system as part of the $\mathrm{CO}$ oxidation with $\mathrm{O}_{2}$ is attributed to the strong interaction between the $\mathrm{Cu}$ particles and the $\mathrm{CeO}_{2}$ phase. Martinez-Arias et al. [7] proposed that $\mathrm{CO}$ reacts with oxygen in the $\mathrm{Cu}-\mathrm{CeO}$ interface, even at room temperature to produce $\mathrm{CO}_{2}$ resulting in $\mathrm{Cu}^{1+}$ and $\mathrm{Ce}^{2+}$ formation and leaving an oxygen vacancy in the interface. Another molecule of $\mathrm{CO}$ can be adsorbed on the $\mathrm{Cu}^{1+}$, which accounts for the observation of this species by IR during the reaction. Re-oxidation of the surface occurs by the adsorption of $\mathrm{O}_{2}$ from the gas phase in a mechanism of the Mars Van Krevelen type. The limiting reaction step should be some of the stages of re-oxidation of the catalyst (migration and/or dissociation of oxygen). The controversy on the exact nature of the active sites, the oxidation state of copper, and the reaction mechanism continues [8-11], but what is clear is that the sites are located on the interface between $\mathrm{Cu}$ and $\mathrm{Ce}$. Regarding the WGS reaction, the generation of oxygen vacancies in the interface has often been cited as the reason for the high activity of this system. Indeed, in the redox mechanism used to explain this reaction, it is proposed that the $\mathrm{H}_{2} \mathrm{O}$ molecule adsorbs on an oxygen vacancy, where the abstraction of oxygen and the generation of $\mathrm{H}_{2}$ takes place. Subsequently, the oxygen atom is removed by $\mathrm{CO}$ which is adsorbed on a neighboring $\mathrm{Cu}$ site in the interface, generating a new oxygen vacancy on the surface and allowing the catalytic cycle to continue $[3,12]$.

It was recently reported that the $\mathrm{CuO}-\mathrm{CeO}_{2}$ system is also a highly active component in the direct decomposition of $\mathrm{N}_{2} \mathrm{O}$ into $\mathrm{N}_{2}$ and $\mathrm{O}_{2}$ [13-16]. This system generates a complete $\mathrm{N}_{2} \mathrm{O}$ decomposition in a stream of $2500 \mathrm{ppm}$ of $\mathrm{N}_{2} \mathrm{O}$ at temperatures below $550{ }^{\circ} \mathrm{C}[16]$. The abatement of $\mathrm{N}_{2} \mathrm{O}$ is very important in controlling greenhouse gases, since it is known that, besides being a toxic gas, $\mathrm{N}_{2} \mathrm{O}$ contributes heavily to the greenhouse effect [16]. One of the main sources of $\mathrm{N}_{2} \mathrm{O}$ is the industrial production of nitric acid by ammonia oxidation [13] There are different options for abating $\mathrm{N}_{2} \mathrm{O}$ depending on where the catalytic process is performed. It has been found that the best choices for existing plants, are locating the catalyst just under the Pt metal gauze in the ammonia burner (process-gas option), or in the tail-gas train (tail-gas option) [13]. In the first option, the catalyst must be able to withstand high temperatures, near $850^{\circ} \mathrm{C}$, while in the latter, conditions and temperatures are more moderate and the catalyst must work at temperatures near $500{ }^{\circ} \mathrm{C}$. Some commercial catalysts for $\mathrm{N}_{2} \mathrm{O}$ process-gas decomposition are: $\mathrm{CuO} / \mathrm{Al}_{2} \mathrm{O}_{3}$ (BASF), $\mathrm{La}_{08} \mathrm{Ce}_{02} \mathrm{CoO}$

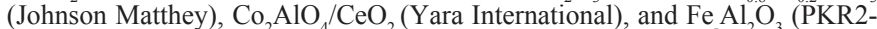
INS). Furthermore, Uhde EnviNOx® markets a tail-gas process for removing $\mathrm{N}_{2} \mathrm{O}$ and $\mathrm{NOx}$ that uses iron-containing zeolites.

Considering the moderate temperature range that was studied in the $\mathrm{CuO}$

$-\mathrm{CeO}_{2}$ system (ambient to $700^{\circ} \mathrm{C}$ ) $[15,16,13]$, in principle, these catalysts could be used in a tail-gas process. The high activity of the $\mathrm{CuO}-\mathrm{CeO}_{2}$ system in $\mathrm{N}_{2} \mathrm{O}$ decomposition was attributed to the existence of oxygen vacancies in the interface of the $\mathrm{Cu}-\mathrm{Ce}$ sites that stabilize $\mathrm{Cu}^{+}$, which is responsible for the abstraction of the oxygen atom from the $\mathrm{N}_{2} \mathrm{O}$ molecule [14].

As shown in all these reactions, as well as other reactions catalysed by the $\mathrm{CuO}-\mathrm{CeO}_{2}$ system, the formation of the $\mathrm{Cu}-\mathrm{CeO}_{2}$ interface is essential for obtaining a catalytically active system. In many cases, the $\mathrm{Cu}-\mathrm{CeO}$ system is formed either by co-precipitating the precursors of both metals or by using a method that leads to the formation of mixed oxides $[14,15]$ or by supporting $\mathrm{Cu}$ on previously formed $\mathrm{CeO}_{2}[15,16]$. Indeed, all reports that discuss the activity of the $\mathrm{CuO}-\mathrm{CeO}_{2}$ system in decomposing $\mathrm{N}_{2} \mathrm{O}$ [13-16], use $\mathrm{Cu}$ catalysts that are supported on $\mathrm{CeO}_{2}$ or use mixed oxides prepared by coprecipitation. A disadvantage to these catalysts is that they are produced with specific areas below $100 \mathrm{~m}^{2} / \mathrm{g}$ [18], and most often, even areas of less than $50 \mathrm{~m}^{2} / \mathrm{g}$ [19, 20], unless special methods of preparation are used, such as a reversed micro emulsion method [8] in which the mixed oxide reaches areas between 130 and $150 \mathrm{~m}^{2} / \mathrm{g}$ after calcination at $500{ }^{\circ} \mathrm{C}$. Furthermore, the specific surface area of these catalysts decreases strongly with increasing calcination temperature. Djinovic at al. [21] show that the specific surface area of a $\mathrm{CuO} / \mathrm{CeO}_{2}$ catalyst decreases from $40.2 \mathrm{~m}^{2} / \mathrm{g}$ (at $450^{\circ} \mathrm{C}$ ), to only $8.3 \mathrm{~m}^{2} / \mathrm{g}$ after calcining at 550 ${ }^{\circ} \mathrm{C}$. With the goal of improving the thermal stability of $\mathrm{CeO}_{2}$, the addition of some dopants such as $\mathrm{ZrO}_{2}$ or $\mathrm{La}_{2} \mathrm{O}_{3}$ to the cerium oxide has been explored $[22,23]$. Alternatively, the $\mathrm{CuO}-\mathrm{CeO}_{2}$ system could be supported on a third oxide with high specific surface area and high thermal stability, with the added advantage that the catalyst acquires the mechanical properties of the support [24]. Regardless of the reason for using a third oxide for support, it is important for the $\mathrm{Cu}$ and $\mathrm{CeO}_{2}$ to interact on the support's surface forming a $\mathrm{Cu}-\mathrm{CeO}$ interface with a high interfacial area.

In our laboratory, in recent years we have conducted a series of studies using monometallic $\mathrm{CuO}$ catalysts and bimetallic $\mathrm{CuO}-\mathrm{CeO}$, catalysts supported on different oxides that are commonly used as supports: $\mathrm{SiO}_{2}, \mathrm{Al}_{2} \mathrm{O}_{3}$, and $\mathrm{ZrO}_{2}$ [25]. Reactions in which these catalysts have been tested include the $\mathrm{CO}$ oxidation with $\mathrm{O}_{2}$ and the WGS reaction. 
In the oxidation reaction of $\mathrm{CO}$ with $\mathrm{O}_{2}$ on a $\mathrm{Cu}$ supported monometallic catalyst, the support plays an important role in the activity of the catalysts as shown by the significantly greater activity generated by zirconium oxide catalysts compared to that seen with $\mathrm{SiO}_{2}$ and $\mathrm{Al}_{2} \mathrm{O}_{3}$ supports [25]. Regardless of the support used, the addition of $\mathrm{CeO}_{2}$ generates bimetallic catalysts that are much more active than the monometallic ones. This increase in activity is due to the formation of the $\mathrm{Cu}-\mathrm{CeO}$ interface on the support's surface, as indicated by various catalyst characterization techniques [25, 26]. However, the formation of the $\mathrm{Cu}-\mathrm{CeO}$ interface does not occur in the same way on all supports. In fact, when using $\mathrm{SiO}_{2}$ as support, $\mathrm{Cu}-\mathrm{CeO}_{2}$ generates a more active interface, while the $\mathrm{Al}_{2} \mathrm{O}_{3}$ support generates a less active interface. This was attributed to the inert character of the silica, which promotes the formation of an interface similar to that formed by supporting $\mathrm{Cu}$ directly on $\mathrm{CeO}_{2}$

While the inert character of the silica seems to be favorable for the formation of a $\mathrm{Cu}-\mathrm{CeO}$ interface that is highly active in the oxidation of $\mathrm{CO}$ with $\mathrm{O}_{2}$ and in the WGS reactions, inertness can generate a problem with the stability of this interface at high temperatures. Indeed, if a catalyst with $2 \% \mathrm{Cu}$ and $8 \% \mathrm{Ce}$, prepared by coimpregnation of the nitrates of both metals on $\mathrm{SiO}_{2}$ (Aerosil 200), is calcined at $500{ }^{\circ} \mathrm{C}$, a highly active catalyst for $\mathrm{CO}$ oxidation is obtained which has a practically $100 \%$ conversion rate below $140{ }^{\circ} \mathrm{C}$. However, if the calcination temperature is increased to $650{ }^{\circ} \mathrm{C}$ or higher temperatures, a marked decrease in catalytic activity occurs, falling to practically 0 when calcining at $700{ }^{\circ} \mathrm{C}$ [26]. The characterization of the catalysts calcined at different temperatures show that the $\mathrm{Cu}-\mathrm{CeO}_{2}$ interface practically disappears due to calcination at $700{ }^{\circ} \mathrm{C}$, accounting for its sharp drop in activity. It is reasonable to assume that the inert character of $\mathrm{SiO}_{2}$ facilitates both the migration and sintering of $\mathrm{Cu}$ and $\mathrm{Ce}$ species, reducing the $\mathrm{Cu}-\mathrm{CeO}_{2}$ interface sites on the carrier's surface.

Since it is known that $\mathrm{Cu}$ can interact with the $\mathrm{Al}_{2} \mathrm{O}_{3}$ support $[27,28]$, especially at low loads, it is also reasonable to assume that the thermal stability of the $\mathrm{Cu}-\mathrm{CeO}_{2}$ interface formed on this oxide can be greater than that formed on the essentially inert $\mathrm{SiO}_{2}$ surface. This is the hypothesis that gives rise to the present paper, where the effect of the supports, $\mathrm{SiO}_{2}$ and $\mathrm{Al}_{2} \mathrm{O}_{3}$, on the topography of the $\mathrm{Cu}-\mathrm{CeO}_{2}$ interface and on its stability under calcination between $500{ }^{\circ} \mathrm{C}$ and $900{ }^{\circ} \mathrm{C}$ is compared. The activity of the catalysts in the $\mathrm{CO}$ oxidation and $\mathrm{N}_{2} \mathrm{O}$ decomposition reactions are used as test reactions, because both reactions are highly dependent on the existence of the $\mathrm{Cu}-\mathrm{CeO}$ interface.

Although the oxidation reactions of $\mathrm{CO}$ can occur at temperatures considered moderate, below $300{ }^{\circ} \mathrm{C}$, in other reactions such as the process-gas option for decomposing $\mathrm{N}_{2} \mathrm{O}$, the temperature can be in the range of 850 to $900{ }^{\circ} \mathrm{C}$, justifying the study of the stability of the $\mathrm{Cu}-\mathrm{CeO}$ interface at high temperatures

\section{2.- EXPERIMENTAL}

2.1 Catalyst Preparation

The catalysts were prepared by coimpregnation of the support with a solution containing $\mathrm{Cu}$ and $\mathrm{Ce}$ nitrates, with a total loading of $2 \% \mathrm{Cu}$ and $8 \%$ $\mathrm{Ce}$. They were then dried at $105{ }^{\circ} \mathrm{C}$ overnight and calcined at the required temperature, $500{ }^{\circ} \mathrm{C}, 700{ }^{\circ} \mathrm{C}$, and $900{ }^{\circ} \mathrm{C}$. The supports used were commercial $\mathrm{SiO}_{2}$ (Aerosil 130) and $\gamma-\mathrm{Al}_{2} \mathrm{O}_{3}$ (Sigma-Aldrich). The catalysts will be denoted as $\mathrm{Cu} / \mathrm{X}-\mathrm{Y}$ and $\mathrm{CuCe} / \mathrm{X}-\mathrm{Y}$, where $\mathrm{X}$ is the support silica ( $\mathrm{Si}$ ) or alumina (Al), and $\mathrm{Y}$ is the catalysts calcination temperature $(500,700$ or 900$)$.

2.2 Catalyst Characterization

The samples were characterized by $\mathrm{N}_{2}$ adsorption, X-ray diffraction (XRD), temperature-programmed reduction in a hydrogen stream (TPR), and UV-vis DRS.

The determination of the specific surface area of the catalysts was made by measuring $\mathrm{N}_{2}$ adsorption in a model ASAP 2010 Micromeritics sorptometer. The samples were previously degassed at $200{ }^{\circ} \mathrm{C}$.

The crystal structure of the different catalysts was determined on a Siemens D-5000 diffractometer using $\mathrm{Cu} \mathrm{K} \alpha$ radiation and a scan rate of 0.02 degrees per minute.

The temperature-programmed reduction analyses were made on a conventional system equipped with a TCD detector, with a flow of $20 \mathrm{~cm}^{3} / \mathrm{min}$ of a gaseous mixture of $5 \% \mathrm{H}_{2}$ in $\mathrm{Ar}$, and a heating ramp of $10{ }^{\circ} \mathrm{C} / \mathrm{min}$ between ambient temperature and $700^{\circ} \mathrm{C}$.

Finally, the UV-vis DRS analyses were made on a Perkin Elmer Lambda 650 instrument equipped with a Harrick Praying Mantis and powder cell.

2.3 Measurement of Catalyst Activity

CO oxidation: The kinetics tests were made in a piston flow tubular reactor, with $2 \% \mathrm{CO}$ and $3 \% \mathrm{O}$ streams at a total flow rate of $100 \mathrm{~cm}^{3} /$ minutes. After loading the reactor with $0.1 \mathrm{~g}$ of catalyst, the sample was pretreated at
$300{ }^{\circ} \mathrm{C}$ for one hour in $\mathrm{O}_{2}$, and the reactor was cooled to room temperature. The reactants were then fed and the temperature was increased at a rate of $3{ }^{\circ} \mathrm{C} / \mathrm{min}$, taking samples every $20^{\circ} \mathrm{C}$ to determine the concentration of $\mathrm{CO}, \mathrm{O}_{2}$, and $\mathrm{CO}$ on a Perkin Elmer Autosystem chromatograph with a CTR column (Alltech) and a TCD detector.

$N_{2} O$ decomposition: The catalytic activity tests were also performed in a piston flow tubular reactor, with a flow of $5000 \mathrm{ppm} \mathrm{N} \mathrm{O}$ balanced in $\mathrm{He}$, at a total flow rate of $100 \mathrm{~cm}^{3} / \mathrm{min}$, operated at atmospheric pressure. After loading the reactor with $0.35 \mathrm{~g}$ of catalyst, the catalyst was pretreated at $400{ }^{\circ} \mathrm{C}$ with $\mathrm{O}_{2}$ for $30 \mathrm{~min}$ and then at $600{ }^{\circ} \mathrm{C}$ for $1 \mathrm{~h}$ with $\mathrm{He}$. After the pretreatment, the reactor temperature was decreased to $350{ }^{\circ} \mathrm{C}$, and the reactant $\left(\mathrm{N}_{2} \mathrm{O}\right.$ balanced in $\mathrm{He}$ ) was then fed to the reactor. After $30 \mathrm{~min}$ of $\mathrm{N}_{2} \mathrm{O}$ flow, the temperature was increased from $400{ }^{\circ} \mathrm{C}$ to $600{ }^{\circ} \mathrm{C}$, taking samples every $25^{\circ} \mathrm{C}$ to determine the concentration of $\mathrm{N}_{2} \mathrm{O}$ on a Perkin Elmer Autosystem chromatograph equipped with a HAYASEP D column and a TCD detector.

\section{3.- RESULTS}

3.1 Characterization of the catalysts

Table 1 shows the BET area of the different mono- and bimetallic catalysts. In the case of the $\mathrm{SiO}_{2}$ support, increasing the calcination temperature from 500 to $900{ }^{\circ} \mathrm{C}$ has little effect on the specific surface area of the catalysts, as expected from the high thermal stability of silica. In the case of the monometallic $\mathrm{Cu}$ catalysts, the specific surface area decreases from 130 to 110 $\mathrm{m}^{2} / \mathrm{g}$ when calcining between 500 and $900{ }^{\circ} \mathrm{C}$, while in the bimetallic $\mathrm{Cu}-\mathrm{Ce}$ catalysts the specific surface area decreases from 128 to $104 \mathrm{~m}^{2} / \mathrm{g}$ over the same calcination temperature range.

In the case of the $\mathrm{Al}_{2} \mathrm{O}_{3}$ support, in the monometallic $\mathrm{Cu}$ as well as in the bimetallic $\mathrm{Cu}-\mathrm{Ce}$ catalysts, increasing the calcination temperature of the catalyst has some effect on the specific surface area between $500{ }^{\circ} \mathrm{C}$ and 700 ${ }^{\circ} \mathrm{C}$. In the case of the monometallic catalysts, the area varies between 130 and $111 \mathrm{~m}^{2} / \mathrm{g}$ when calcining between 500 and $700{ }^{\circ} \mathrm{C}$, while with the bimetallic catalysts the area decreases from 109 to $96 \mathrm{~m}^{2} / \mathrm{g}$ for the same temperature range. However, with calcining at $900{ }^{\circ} \mathrm{C}$, the specific surface area of the mono- and bimetallic catalysts decreases to around $60 \mathrm{~m}^{2} / \mathrm{g}$, showing the lower thermal stability of alumina.

Table 1. BET specific surface area and $\mathrm{H}_{2}$ consumption of the various monometallic and bimetallic catalysts.

\begin{tabular}{|c|c|c|c|}
\hline Catalyst & $\begin{array}{c}\text { BET Surface } \\
\text { Area }\left(\mathrm{m}^{2} / \mathrm{g}\right)\end{array}$ & $\begin{array}{c}\text { Ratio of: } \mathrm{H}_{2} \\
\text { consumed / } \\
\mathrm{H}_{2} \text { required } \\
\text { for complete } \\
\text { reduction of } \mathrm{CuO}\end{array}$ & $\begin{array}{c}\mathrm{CeO}_{2} \text { particle } \\
\text { diameter } \\
(\mathrm{nm})\end{array}$ \\
\hline \multicolumn{4}{|l|}{ Monometallic } \\
\hline $\mathrm{Cu} / \mathrm{Si}-500$ & 130 & 0.99 & - \\
\hline $\mathrm{Cu} / \mathrm{Si}-700$ & 120 & 1.01 & - \\
\hline $\mathrm{Cu} / \mathrm{Si}-900$ & 110 & 1.02 & - \\
\hline $\mathrm{Cu} / \mathrm{Al}-500$ & 130 & 0.82 & - \\
\hline $\mathrm{Cu} / \mathrm{Al}-700$ & 111 & 0.60 & - \\
\hline $\mathrm{Cu} / \mathrm{Al}-900$ & 60 & 0.59 & - \\
\hline \multicolumn{4}{|l|}{ Bimetallic } \\
\hline $\mathrm{CuCe} / \mathrm{Si}-500$ & 128 & 1.33 & 6.0 \\
\hline $\mathrm{CuCe} / \mathrm{Si}-700$ & 128 & 1.08 & 6.8 \\
\hline $\mathrm{CuCe} / \mathrm{Si}-900$ & 104 & 0.99 & 12.0 \\
\hline $\mathrm{CuCe} / \mathrm{Al}-500$ & 109 & 1.04 & 5.7 \\
\hline $\mathrm{CuCe} / \mathrm{Al}-700$ & 96 & 0.69 & 6.3 \\
\hline $\mathrm{CuCe} / \mathrm{Al}-900$ & 58 & 0.64 & 7.1 \\
\hline
\end{tabular}

The effect of the calcination temperature on the crystal structure of 
the catalysts supported on $\mathrm{SiO}_{2}$ is shown in Figure 1A. In the case of the monometallic catalysts, the peaks of the tenorite structure of $\mathrm{CuO}$ at $2 \theta=35.5^{\circ}$ and $38.7^{\circ}$ are seen clearly in all the catalysts calcined between $500{ }^{\circ} \mathrm{C}$ and 900 ${ }^{\circ} \mathrm{C}: \mathrm{Cu} / \mathrm{Si}-500, \mathrm{Cu} / \mathrm{Si}-700$ and $\mathrm{Cu} / \mathrm{Si}-900$. These results confirm what has been reported previously $[25,26]$, and show that $\mathrm{Cu}$ forms crystalline $\mathrm{CuO}$ particles on silica, even at low calcination temperatures $\left(500{ }^{\circ} \mathrm{C}\right)$. In contrast, in the diffractograms of the bimetallic $\mathrm{Cu}-\mathrm{Ce}$ catalysts, the $\mathrm{CuO}$ peaks are no longe seen in the catalysts calcined at $500{ }^{\circ} \mathrm{C}(\mathrm{CuCe} / \mathrm{Si}-500)$ and $700{ }^{\circ} \mathrm{C}(\mathrm{CuCe} / \mathrm{Si}-$ 700 ), and they can only be seen weakly in the bimetallic catalyst calcined at $900{ }^{\circ} \mathrm{C}(\mathrm{CuCe} / \mathrm{Si}-900)$. The effect of the increased dispersion of $\mathrm{Cu}$ by adding $\mathrm{CeO}_{2}$ has been reported in the literature $[25,26,29]$, so it is not strange for the $\mathrm{CuO}$ peaks to disappear in the bimetallic catalysts calcined at $500{ }^{\circ} \mathrm{C}$ and $700{ }^{\circ} \mathrm{C}$.
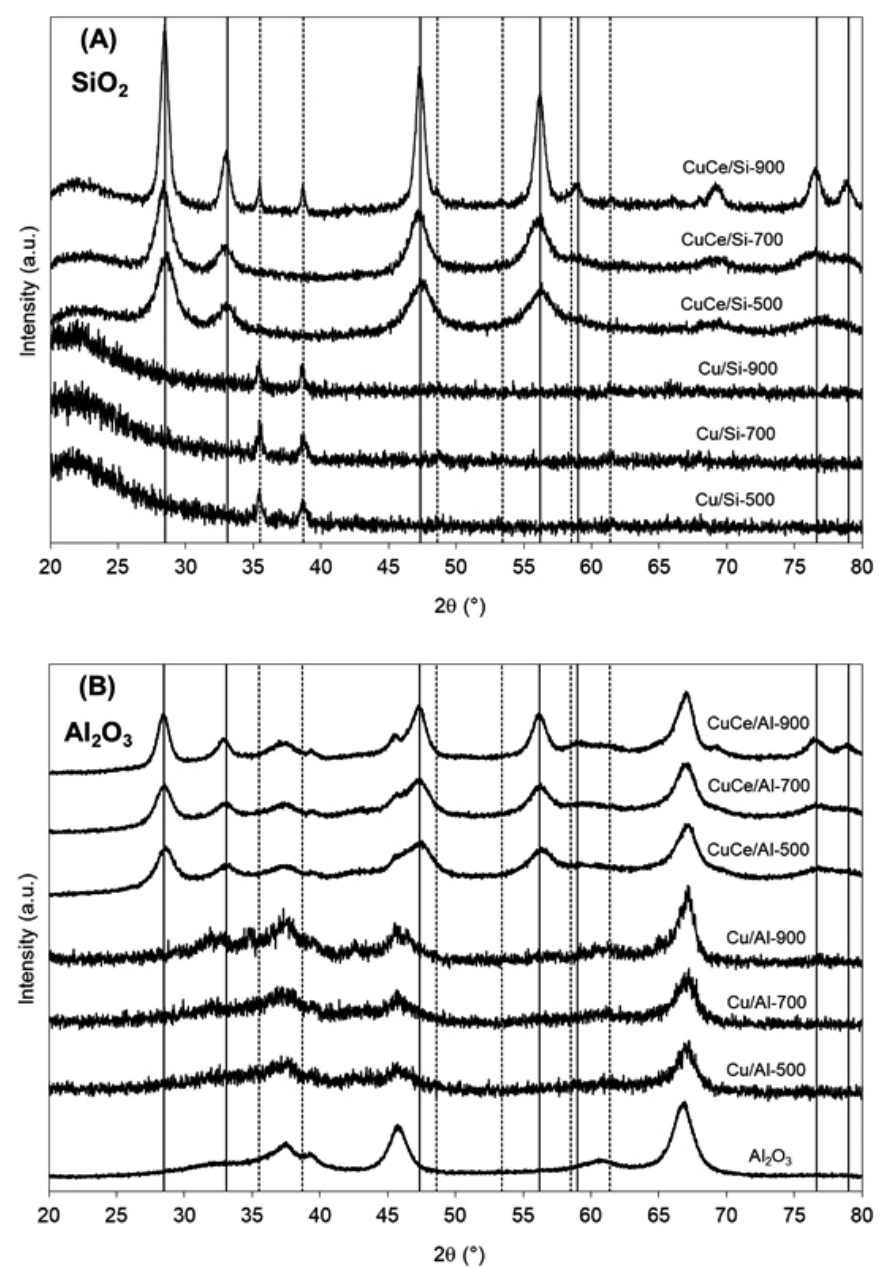

Figure 1: XRD patterns of monometallic $(\mathrm{Cu})$ and bimetallic $(\mathrm{CuCe})$ catalysts calcined at $500{ }^{\circ} \mathrm{C}, 700{ }^{\circ} \mathrm{C}$ and $900{ }^{\circ} \mathrm{C}$. (A) Supported on $\mathrm{SiO}_{2}$; (B) Supported on $\mathrm{Al}_{2} \mathrm{O}_{3}$. The diffraction lines of $\mathrm{CuO}(\cdots \cdots)$ and $\mathrm{CeO}_{2}(-)$ are indicated as reference. Operation conditions: scan range $=20-80^{\circ}$; scan rate $=0.02$ degrees per minute.

The appearance of the $\mathrm{CuO}$ peak at $900{ }^{\circ} \mathrm{C}$ is, therefore, a clear indication of substantial segregation of $\mathrm{CuO}$ and $\mathrm{CeO}_{2}$ on the silica surface of $\mathrm{CuCe} / \mathrm{Si}$ 900 catalyst. In all the bimetallic catalysts the peaks at $2 \theta=28.6^{\circ}, 33.1^{\circ}, 47.5^{\circ}$ and $56.4^{\circ}$, attributable to the fluorite structure of cerium oxide, are clearly seen. In the case of the catalyst calcined at $900{ }^{\circ} \mathrm{C}$, the peaks of $\mathrm{CeO}_{2}$ at $2 \theta=59.0^{\circ}$, $76.7^{\circ}$, and $79.2^{\circ}$ are also visible. The particle size of $\mathrm{CeO}_{2}$ calculated by means of Scherrer's equation is also given in Table 1. As expected, the temperature increase leads to a strong growth of the $\mathrm{CeO}_{2}$ particle size, from $6.0 \mathrm{~nm}$ after calcination at $500{ }^{\circ} \mathrm{C}$, to $12.0 \mathrm{~nm}$ after calcination at $900{ }^{\circ} \mathrm{C}$.

Figure 1B shows the diffractograms of catalysts supported on alumina. The diffractograms of all the catalysts are dominated by the peaks corresponding to $\gamma$-alumina. Those located at $2 \theta=37.6,39.5,45.8,60.5$, and $66.8^{\circ}$ are the most intense. Regardless of the calcination temperature, the peaks corresponding to $\mathrm{CuO}$ or crystalline $\mathrm{CuAl}_{2} \mathrm{O}_{4}$ are not found in any of the catalysts. The classic studies of Friedman et al. [27] and Stromehier et al. [28] show that at low loads the $\mathrm{Cu}$ enters the defect spinel of the $\gamma$-alumina support to yield a well dispersed phase which is not detected by X-ray diffraction $[27,28]$. This $\mathrm{Cu}$ structure is usually cited as "copper aluminate surface phase" because it "resembles" the $\mathrm{CuAl}_{2} \mathrm{O}$ phase. According to these authors, as long as the $\mathrm{Cu}$ load does not exceed $4 \%-5 \%$ for every $100 \mathrm{~m}^{2} / \mathrm{g}$, the appearance of $\mathrm{CuO}$ is not expected $[27,28]$. Considering the above, it is not strange that in our catalysts the formation of crystalline $\mathrm{CuO}$ is not seen. On the other hand, the formation of $\mathrm{Cu}$ aluminate can be observed by XRD at greater $\mathrm{Cu}$ loads and higher calcination temperatures. In fact, Luo et al. [30] report the formation of $\mathrm{Cu}$ aluminate in catalysts with $11 \%$ or higher loads at temperatures above 800 ${ }^{\circ} \mathrm{C}$. Because of this, no copper aluminate is expected in our catalysts. In the case of the bimetallic $\mathrm{Cu}-\mathrm{Ce}$ catalysts, $\mathrm{CeO}_{2}$ peaks are seen at $2 \theta=28.6,33.1$, 47.6, and $56.4^{\circ}$. As reported in Table 1, although the size of the $\mathrm{CeO}_{2}$ crystal increases from $5.7 \mathrm{~nm}$ at $500{ }^{\circ} \mathrm{C}$ to $7.1 \mathrm{~nm}$ at $900^{\circ} \mathrm{C}$, this increase is noticeably less than that observed in the catalysts supported on silica. It is clear, therefore, that the greater interaction of the $\mathrm{CeO}_{2}$ particles with alumina decreases the degree of sintering with the temperature increase. The peaks corresponding to crystalline $\mathrm{CuO}$ are not detected by XRD in any of the catalysts, regardless of the calcination temperature, for the reasons already discussed for the monometallic catalysts supported on alumina.

The results of the temperature programmed reduction (TPR) experiments using $\mathrm{H}_{2}$ as reductant are shown in Figure 2A for silica supported catalysts, and Figure $2 \mathrm{~B}$ for alumina supported catalysts.

In the case of the monometallic catalysts supported on $\mathrm{SiO}_{2}$, there is only one reduction peak, with a maximum that is displaced from $290^{\circ} \mathrm{C}$ to $308^{\circ} \mathrm{C}$ by calcining between 500 and $900{ }^{\circ} \mathrm{C}$ (Figure 2A). This peak has been seen in previous work by our group [25], and, according to the literature, it can be associated with bulk $\mathrm{CuO}$ [31-33]. The assignment of this peak to bulk $\mathrm{CuO}$ agrees with what has been observed in the XRD diffractograms, which show clearly the formation of crystalline $\mathrm{CuO}$ in all the monometallic $\mathrm{Cu}$ catalysts supported on silica. Table 1 reports the consumption of $\mathrm{H}_{2}$ by the different catalysts, expressed as the ratio between the consumed $\mathrm{H}_{2}$ and the $\mathrm{H}_{2}$ required to reduce all the $\mathrm{Cu}^{2+}$ to $\mathrm{Cu}^{0}$. All the fractions are very close to 1.0 , indicating that the reduction of the $\mathrm{Cu}$ oxide to metallic $\mathrm{Cu}$ is complete in the temperature range used in the TPR experiments.

In the case of the bimetallic catalysts, with the catalysts calcined at $500{ }^{\circ} \mathrm{C}$ $(\mathrm{CuCe} / \mathrm{Si}-500)$, the reduction occurs at a considerably lower temperature than with the monometallic catalysts. In effect, two reduction peaks are seen with maxima at 195 and $214^{\circ} \mathrm{C}$. The appearance of two reduction peaks agrees with what was seen in previous work [25, 26]. According to the literature the first peak is associated with the reduction of highly dispersed $\mathrm{Cu}$ species in contact with $\mathrm{CeO}_{2}$, and the second peak with the reduction of $\mathrm{Cu}$ particles (clusters), but also in contact with $\mathrm{CeO}_{2}$. On the other hand, as shown in Table 1, the ratio of the consumption of $\mathrm{H}_{2}$ is greater than 1, indicating that another species is being reduced together with $\mathrm{Cu}$ species. The literature reports that $\mathrm{CeO}_{2}$ is reduced above $380{ }^{\circ} \mathrm{C}$, but when $\mathrm{Cu}$ interacts with the $\mathrm{CeO}$ particles part of the $\mathrm{CeO}_{2}$ is reduced together with the $\mathrm{Cu}[4,25,34]$, therefore accounting for a ratio greater than 1 . Therefore, the result shown in Table $1($ ratio $=1.33)$ confirms the idea that the $\mathrm{Cu}$ species are interacting strongly with $\mathrm{CeO}_{2}$ in the catalysts calcined at $500{ }^{\circ} \mathrm{C}$. As the calcination temperature is increased to $700{ }^{\circ} \mathrm{C}$, only one maximum is seen around $265^{\circ} \mathrm{C}$, which can be associated with larger $\mathrm{Cu}$ particles interacting with $\mathrm{CeO}_{2}$. At the same time, the overconsumption of $\mathrm{H}_{2}$ reported in Table 1 decreases strongly in this catalyst (ratio $=1.08)$, suggesting that the interaction between $\mathrm{Cu}$ and $\mathrm{CeO}_{2}$ also decreases by calcining at $700^{\circ} \mathrm{C}$. Finally, calcining at $900{ }^{\circ} \mathrm{C}$ a single peak is seen with a maximum at $308^{\circ} \mathrm{C}$, which can be assigned to the reduction of bulk $\mathrm{CuO}$ particles that do not interact with $\mathrm{CeO}_{2}$. In fact, this peak is located at practically the same temperature as the one seen in the monometallic catalyst. Again, this assignment agrees with the XRD results, which show the formation of crystalline $\mathrm{CuO}$ when calcining the bimetallic catalyst at $900{ }^{\circ} \mathrm{C}$. Furthermore, the results of the consumption of $\mathrm{H}_{2}$ shown in Table 1 (ratio $=0.99$ ) indicates that in this catalyst there is practically no overconsumption of $\mathrm{H}_{2}$, and therefore the only species that is reduced is $\mathrm{CuO}$, reflecting the separation of the $\mathrm{CuO}$ and $\mathrm{CeO}_{2}$ particles on the surface of the $\mathrm{SiO}_{2}$ support when calcining at $900{ }^{\circ} \mathrm{C}$.

The $\mathrm{H}_{2}$ consumption curves (TPR) of catalysts supported on alumina are shown in Figure 2B. In the case of monometallic catalyst calcined at $500{ }^{\circ} \mathrm{C}$ $(\mathrm{Cu} / \mathrm{Al}-500)$, there is a main reduction peak with a maximum at $280^{\circ} \mathrm{C}$. The literature is somewhat contradictory in assigning this reduction peak. At low $\mathrm{Cu}$ loads, Dow et al. [35] report a single reduction peak associated with highly dispersed $\mathrm{Cu}$ at about $210^{\circ} \mathrm{C}$, while the formation of bulk $\mathrm{CuO}$ occurs only at 
$\mathrm{Cu}$ loads greater than $5 \%$, generating a second peak with a maximum close to $245^{\circ} \mathrm{C}$. Yao et al. [36] also saw one reduction peak at low $\mathrm{Cu}$ loads, but with a maximum at $300{ }^{\circ} \mathrm{C}$ which they attributed to highly dispersed $\mathrm{Cu}$, forming isolated and two- and three-dimensional small copper clusters. Xiaoyuan et al. [37] also found a single reduction peak with a maximum at $317^{\circ} \mathrm{C}$ for a $1 \% \mathrm{Cu}$ on alumina catalyst calcined at $500{ }^{\circ} \mathrm{C}$ for two hours. Therefore, considering the previous results and the failure to detect $\mathrm{CuO}$ in the XRD tests, this peak at $280{ }^{\circ} \mathrm{C}$ may be associated with highly dispersed $\mathrm{Cu}$. On the other hand, Table 1 shows that the consumption of $\mathrm{H}_{2}$ is lower than that necessary for reducing all the $\mathrm{CuO}$ present in the catalyst (ratio $=0.82$ ), in agreement with previous studies [38].
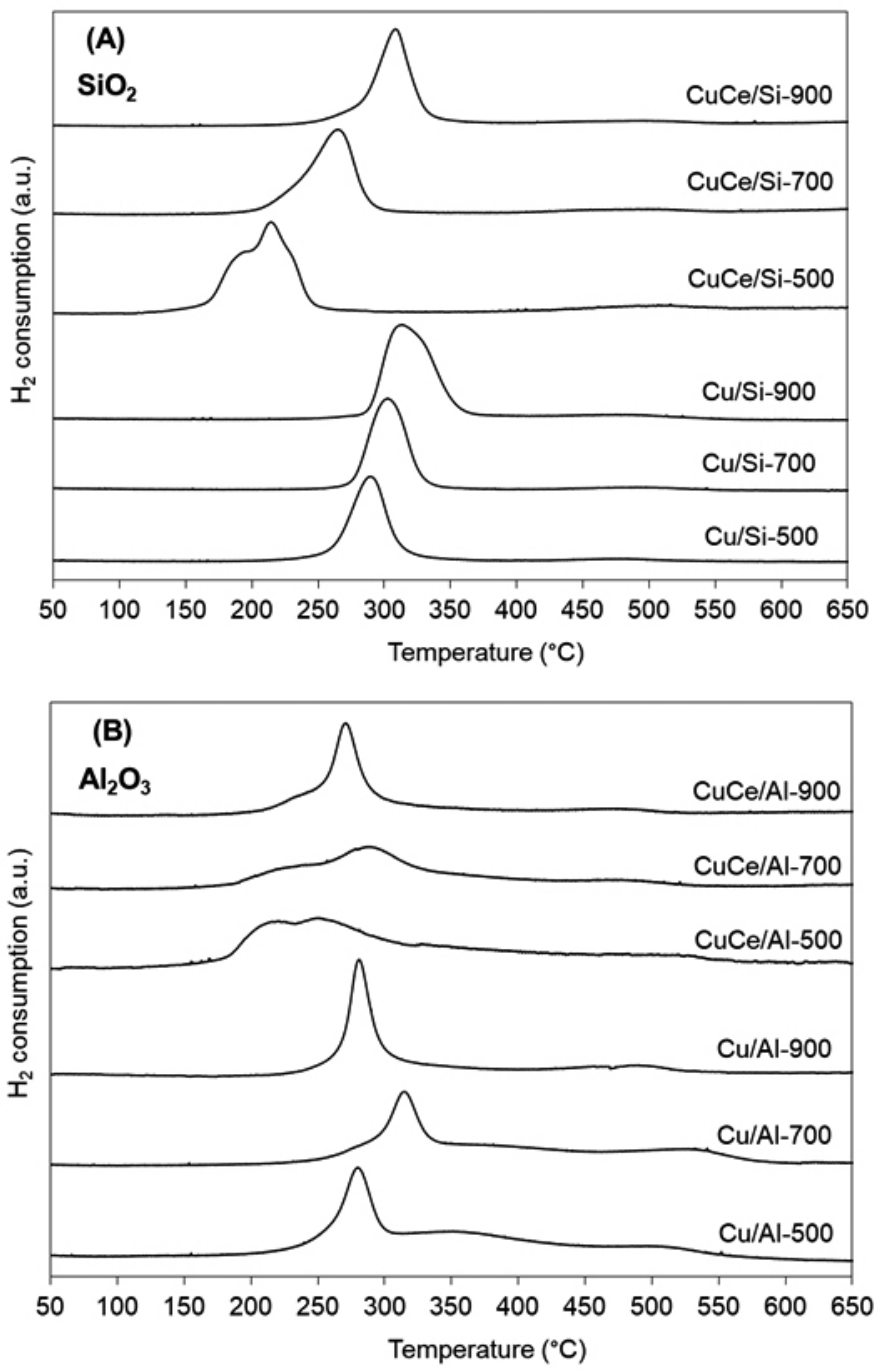

Figure 2: $\mathrm{H}_{2}$-TPR curves of monometallic $(\mathrm{Cu})$ and bimetallic $(\mathrm{CuCe})$ catalysts calcined at $500{ }^{\circ} \mathrm{C}, 700{ }^{\circ} \mathrm{C}$ and $900{ }^{\circ} \mathrm{C}$. (A) Supported on $\mathrm{SiO}_{2}$; (B) Supported on $\mathrm{Al}_{2} \mathrm{O}_{3}$. Operation conditions: flow rate $=20 \mathrm{~cm}^{3} / \mathrm{min}$ of $5 \% \mathrm{H}_{2}$ balance in $\mathrm{He}$; heating rate $=10{ }^{\circ} \mathrm{C} / \mathrm{min}$; catalyst mass $=100 \mathrm{mg}$.

When the calcination temperature is increased to $700{ }^{\circ} \mathrm{C}(\mathrm{Cu} / \mathrm{Al}-700)$, the reduction maximum is displaced to $315^{\circ} \mathrm{C}$, and $\mathrm{H}_{2}$ consumption ratio decreases to 0.60 , indicating that the $\mathrm{Cu}$ is harder to reduce than when calcining at $500{ }^{\circ} \mathrm{C}$. It is frequently found in the literature that increasing the calcination temperature leads to the displacement of the reduction peak to lower temperatures. In fact, Luo et al. [30] and Yahiro et al. [39] show that the reduction peaks are displaced to lower temperatures by calcining between 500 and $700{ }^{\circ} \mathrm{C}$. However, in these cases the high $\mathrm{Cu}$ load, $12 \%$ in the case of Luo et al. and $33 \%$ in the case of Yahiro et al., lead to the formation of $\mathrm{CuO}$, so the displacement to lower temperatures is interpreted by these authors as an increased reduction ease of $\mathrm{CuO}$ due to a redispersion of this species. In our case no bulk $\mathrm{CuO}$ is formed, so the displacement of the reduction peak to higher temperature by calcining at $700{ }^{\circ} \mathrm{C}$ must be explained by the formation of a $\mathrm{Cu}$ species that interacts to a greater degree with the alumina, hindering its reduction. Something similar was reported by Dumas et al. [40], who found that calcining a catalyst with $10 \% \mathrm{Cu}$ at 600 to $750{ }^{\circ} \mathrm{C}$, a simultaneous displacement of the highly dispersed $\mathrm{Cu}$ peak from $242{ }^{\circ} \mathrm{C}$ to $300{ }^{\circ} \mathrm{C}$ took place, while the bulk $\mathrm{CuO}$ peak was displaced from 312 to $300{ }^{\circ} \mathrm{C}$, forming a single reduction peak with a maximum at $300{ }^{\circ} \mathrm{C}$. In other words, calcination at $700{ }^{\circ} \mathrm{C}$ can generate the formation of less reducible species from highly dispersed $\mathrm{Cu}$, at the same time generating more easily reducible species from bulk $\mathrm{CuO}$.

Finally, when the calcination temperature is increased to $900{ }^{\circ} \mathrm{C}(\mathrm{Cu} / \mathrm{Al}-$ 900 ), the ease of reduction of $\mathrm{Cu}$ increases again, and the maximum is displaced to a lower temperature, very close to the one observed for the catalyst calcined at $500{ }^{\circ} \mathrm{C}$. In the literature it is reported that calcination at $900{ }^{\circ} \mathrm{C}$ causes the formation of bulk $\mathrm{CuAl}_{2} \mathrm{O}_{4}$ [28], so this reduction peak may be associated with this species. However, the reduction maximum temperature observed with our catalyst is significantly lower than that reported in the literature for the bulk $\mathrm{CuAl}_{2} \mathrm{O}_{4}$ species. In fact, Severino et al. [38] report that the $\mathrm{CuAl} \mathrm{O}_{4}$ reduction peak is at $445{ }^{\circ} \mathrm{C}$, while Yahiro et al. [39] find the maximum at $410{ }^{\circ} \mathrm{C}$, and Sato et al. [41] report the reduction of $\mathrm{Cu}$ aluminate with a maximum at 450 ${ }^{\circ} \mathrm{C}$. On the other hand, and because of the low $\mathrm{Cu}$ load, our XRD analyses do not allow the formation of $\mathrm{Cu}$ aluminate to be discarded. Therefore, it is only possible to speculate that the peak at $280{ }^{\circ} \mathrm{C}$ corresponds to the reduction of highly dispersed $\mathrm{Cu}$ species. Table 1 shows, however, that $\mathrm{H}_{2}$ consumption (ratio $=0.59$ ) is less than when calcining at $500{ }^{\circ} \mathrm{C}$, so the concentration of reducible $\mathrm{Cu}$ species decreases significantly by calcining between 500 and 900 ${ }^{\circ} \mathrm{C}$. The addition of $\mathrm{CeO}_{2}$ produces important changes in the reduction curves with $\mathrm{H}_{2}$ of the catalysts supported on alumina. The bimetallic catalyst calcined at $500{ }^{\circ} \mathrm{C}$ shows two reduction peaks with reduction temperature maxima between 220 and $250{ }^{\circ} \mathrm{C}$ attributed to $\mathrm{Cu}$ species of different sizes interacting with $\mathrm{CeO}_{2}$, as discussed previously by our group [see ref. 25 and work cited therein]. The $\mathrm{H}_{2}$ consumption with this catalyst, which is reported in Table 1, is also greater than in the monometallic catalyst calcined at the same temperature, confirming the formation of the $\mathrm{Cu}-\mathrm{CeO}_{2}$ interface. Increasing the calcination temperature to $700{ }^{\circ} \mathrm{C}$, the maximum of the first peak remains practically unshifted, but there is a shift of the second reduction peak's maximum from 250 to $290{ }^{\circ} \mathrm{C}$. However, the reduction maxima are lower than the maximum presented by the $\mathrm{Cu}$ monometallic catalyst calcined at $700{ }^{\circ} \mathrm{C}$, reflecting that the $\mathrm{Cu}-\mathrm{CeO}$ interaction has not disappeared completely in the catalyst calcined at $700{ }^{\circ} \mathrm{C}$. Calcining at $900{ }^{\circ} \mathrm{C}$ results in a decrease of the area under the lower temperature peak, but it is clearly seen as a shoulder at $230{ }^{\circ} \mathrm{C}$. In a manner similar to what happens with the monometallic catalyst, the maximum of the higher temperature peak shifts to a reduction temperature lower than that found upon calcining at $700{ }^{\circ} \mathrm{C}$. The maximum is displaced from 290 to 270 ${ }^{\circ} \mathrm{C}$, a temperature $10{ }^{\circ} \mathrm{C}$ lower than that found with the monometallic catalyst, suggesting that there still is an interaction with $\mathrm{CeO}_{2}$. Table 1 shows that there is a slightly greater $\mathrm{H}_{2}$ consumption than in the $\mathrm{Cu}$ monometallic catalyst calcined at the same temperature. Both observations lead to the conclusion that there still are sites corresponding to the $\mathrm{Cu}-\mathrm{CeO}_{2}$ interface in the catalyst calcined at $900^{\circ} \mathrm{C}$.

The UV-vis DRS spectrum of the monometallic and bimetallic catalysts supported on $\mathrm{SiO}_{2}$ is shown in Figure 3A. In the case of monometallic catalysts, the spectrum is dominated by a wide absorption band with a maximum at 660 $\mathrm{nm}$. According to the literature, this band can be assigned to d-d transitions of $\mathrm{Cu}^{2+}$ in bulk $\mathrm{CuO}[42,43]$. In fact, Gang et al. [42] see this band clearly in unsupported $\mathrm{CuO}$. The adsorption edge characteristic of bulk $\mathrm{CuO}$ particles is also clearly seen at wavelengths longer than 750-800 $\mathrm{nm}$ [44]. Therefore, the UV-vis DRS spectra are in perfect agreement with what is seen in the XRD and the TPR observations, which show the formation of bulk $\mathrm{CuO}$ in these catalysts regardless of the calcination temperature. On the other hand, the spectra of the bimetallic catalysts are dominated by the absorption band of cerium oxide. In fact, below $400 \mathrm{~nm}$, the absorption band corresponding to $\mathrm{Ce}^{4+}$-oxygen charge transfer transitions [45] is seen clearly, with a maximum close to 290 $\mathrm{nm}$ for the catalyst calcined at $500{ }^{\circ} \mathrm{C}$, which does not change significantly as the calcination temperature is increased. The zone above $400 \mathrm{~nm}$ is where the largest changes occur as the calcination temperature is increased. The band corresponding to $\mathrm{CuO}$ bulk species supported on $\mathrm{SiO}_{2}$ becomes more intense as the calcination temperature is increased between 500 and $700{ }^{\circ} \mathrm{C}$, and it is clearly observable in the catalyst calcined at $900{ }^{\circ} \mathrm{C}$. Again, this result agrees with the phase separation between $\mathrm{CuO}$ and $\mathrm{CeO}_{2}$, which was inferred from the XRD and TPR analyses. 

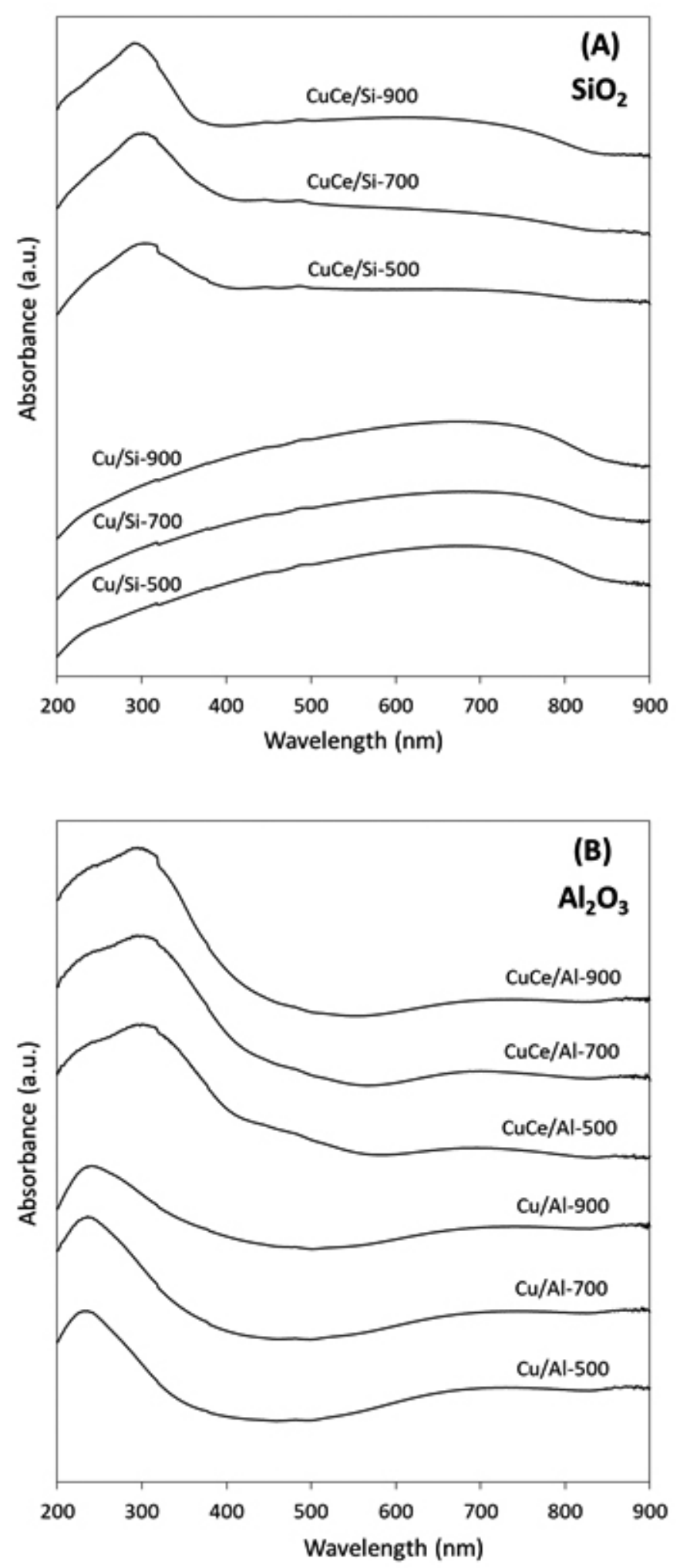

Figure 3: UV-vis DRS spectra of monometallic $(\mathrm{Cu})$ and bimetallic $(\mathrm{CuCe})$ catalysts calcined at $500{ }^{\circ} \mathrm{C}, 700{ }^{\circ} \mathrm{C}$ and $900{ }^{\circ} \mathrm{C}$. (A) Supported on $\mathrm{SiO}_{2} ;$ (B) Supported on $\mathrm{Al}_{2} \mathrm{O}_{3}$.

Figure 3B shows the UV-vis DRS spectra of the monometallic and bimetallic catalysts supported on alumina. The spectrum of the monometallic catalyst calcined at $500{ }^{\circ} \mathrm{C}(\mathrm{Cu} / \mathrm{Al}-500)$ is very similar to those reported previously in the literature for the $\mathrm{CuO} / \mathrm{Al}_{2} \mathrm{O}_{3}$ system $[42,46]$. It is characterized by a band below $400 \mathrm{~nm}$, with a maximum close to $240 \mathrm{~nm}$ that has been attributed to an $\mathrm{O}^{2-} \rightarrow \mathrm{Cu}^{2+}$ ligand-to-metal charge transfer [43], and a wide band with a maximum around $740 \mathrm{~nm}$ attributed to d-d transitions of $\mathrm{Cu}^{2+}$ with octahedral symmetry. It is important to point out that the adsorption edge characteristic of bulk $\mathrm{CuO}$ particles, clearly observable in the monometallic catalysts supported on $\mathrm{SiO}_{2}$, is not seen in any of the catalysts supported on alumina. This is consistent with expectations, in view of the high dispersion of the $\mathrm{Cu}$ on this support observed by XRD. Calcining at a higher temperature does not result in major changes in the spectrum, except a widening of the band between 300 and $400 \mathrm{~nm}$ in the catalyst calcined at $900^{\circ} \mathrm{C}$. This widening may be due to charge transfer involving $\mathrm{Cu}^{2+}-\mathrm{O}^{2-}-\mathrm{Cu}^{2+}$ species, or, possibly, clusterlike species [47]. In the spectrum of the bimetallic catalyst calcined at $500{ }^{\circ} \mathrm{C}$ a large peak is seen in the low wavelength zone, with a maximum at $300 \mathrm{~nm}$ and a shoulder at $240 \mathrm{~nm}$. Considering what has been discussed previously, the former may be associated with $\mathrm{Ce}^{4+}$-oxygen charge transfer transitions, and the latter to an $\mathrm{O}^{2-} \rightarrow \mathrm{Cu}^{2+}$ ligand-to-metal charge transfer. Between 600 and 850 $\mathrm{nm}$, the characteristic band of the $\mathrm{d}-\mathrm{d}$ transitions of $\mathrm{Cu}^{2+}$ are observed, and as in the case of the $\mathrm{CuO} / \mathrm{Al}_{2} \mathrm{O}_{3}$ catalysts, it is not possible to see the adsorption edge characteristic of bulk ${ }^{2} \mathrm{CuO}$ particles. Calcining at higher temperatures results in no important changes in the positions of the maxima of the absorption bands or signs of the adsorption edge of the bulk $\mathrm{CuO}$ particles. The above indicates that, in contrast with what was seen for the bimetallic catalysts supported on $\mathrm{SiO}, \mathrm{Cu}$ retains a high dispersion even in the bimetallic catalyst calcined at $900{ }^{\circ} \mathrm{C}$. This result is in complete agreement with what was observed by $\mathrm{XRD}$, where the $\mathrm{CuO}$ crystalline species is absent in the catalysts supported on alumina calcined between 500 and $900{ }^{\circ} \mathrm{C}$.

\subsection{Catalytic activity}

The conversion of $\mathrm{CO}$ as a function of reaction temperature for the monometallic $\mathrm{Cu}$ catalysts and the bimetallic $\mathrm{Cu}-\mathrm{Ce}$ catalysts supported on $\mathrm{SiO}_{2}$ is shown in Figure 4A. Except for the Cu monometallic catalyst calcined at $500{ }^{\circ} \mathrm{C}$, which presents a $7 \%$ conversion at $220{ }^{\circ} \mathrm{C}$, the monometallic catalysts calcined at 700 and $900{ }^{\circ} \mathrm{C}$ are practically inactive in the temperature range used in this study. The XRD analysis, the TPR experiments, and the UVvis DRS tests show that the $\mathrm{Cu}$ is found forming bulk $\mathrm{CuO}$ on the silica surface, a species that has low activity in the oxidation of $\mathrm{CO}[25,38]$. Adding $\mathrm{CeO}_{2}$, the activity of the catalyst calcined at $500{ }^{\circ} \mathrm{C}$ increases considerably, reaching almost $100 \%$ conversion at $120^{\circ} \mathrm{C}$, as shown in Figure $4 \mathrm{~A}$. The great activity increase observed in the bimetallic catalyst confirms what has been reported extensively in the literature, that the sites of the $\mathrm{Cu}-\mathrm{CeO}_{2}$ interphase have a very high activity in this reaction [1-7]. In fact, the TPR experiments show that there is a strong interaction between the $\mathrm{Cu}$ and $\mathrm{Ce}$ species on the surface of this catalyst. As calcination temperature is increased to $700{ }^{\circ} \mathrm{C}$, the activity drops considerably, in agreement with the decrease of the $\mathrm{Cu}-\mathrm{CeO}_{2}$ interactions, due mainly to the increase of the cerium oxide particle size reported in Table 1. It is interesting to note that in our previous paper [26], calcination at that same temperature of a $\mathrm{Cu}-\mathrm{Ce} / \mathrm{SiO}_{2}$ catalyst of the same composition led to a total inactivation of the catalyst. The only difference with the present catalyst is that in the previous paper a silica with a larger surface area (Aerosil 200) was used, so the area of the support seems to play an important role in the stability of the $\mathrm{Cu}-\mathrm{CeO}$ interface. This will be considered in future studies. Calcination of the bimetallic catalyst at $900{ }^{\circ} \mathrm{C}$ leads to the total inactivation of the catalyst. The TPR experiments show clearly the separation of the $\mathrm{CuO}$ and $\mathrm{CeO}_{2}$ phases in this catalyst, and the XRD results show that this phase separation is associated not only with the large growth of the $\mathrm{CeO}_{2}$ particles on the surface of the silica, but also with the formation of the $\mathrm{CuO}$ bulk phase. The UV-vis DRS analysis of this catalyst confirms also the appearance of bulk $\mathrm{CuO}$ particles in the bimetallic catalyst calcined at $900{ }^{\circ} \mathrm{C}$.

Figure 4B shows the activity of catalysts supported on alumina. The activity of the monometallic $\mathrm{Cu}$ catalysts supported on alumina is low, but, in contrast with the catalysts supported on silica, the catalyst calcined at $900{ }^{\circ} \mathrm{C}$ shows some activity. The catalyst calcined at $900{ }^{\circ} \mathrm{C}$ has an activity slightly higher than that of the catalyst calcined at $700{ }^{\circ} \mathrm{C}$. This result, which seems unexpected, is in agreement with the greater facility of reduction of the catalyst calcined at $900{ }^{\circ} \mathrm{C}$, compared to the one calcined at $700^{\circ} \mathrm{C}$, which was observed in the TPR experiments. This is a point that deserves more attention in future work. As expected, the addition of $\mathrm{CeO}_{2}$ produces a strong increase of the activity of the catalysts. Obviously, the formation of interfacial $\mathrm{Cu}-\mathrm{CeO}$ sites on the surface of alumina explains this activity increase. 

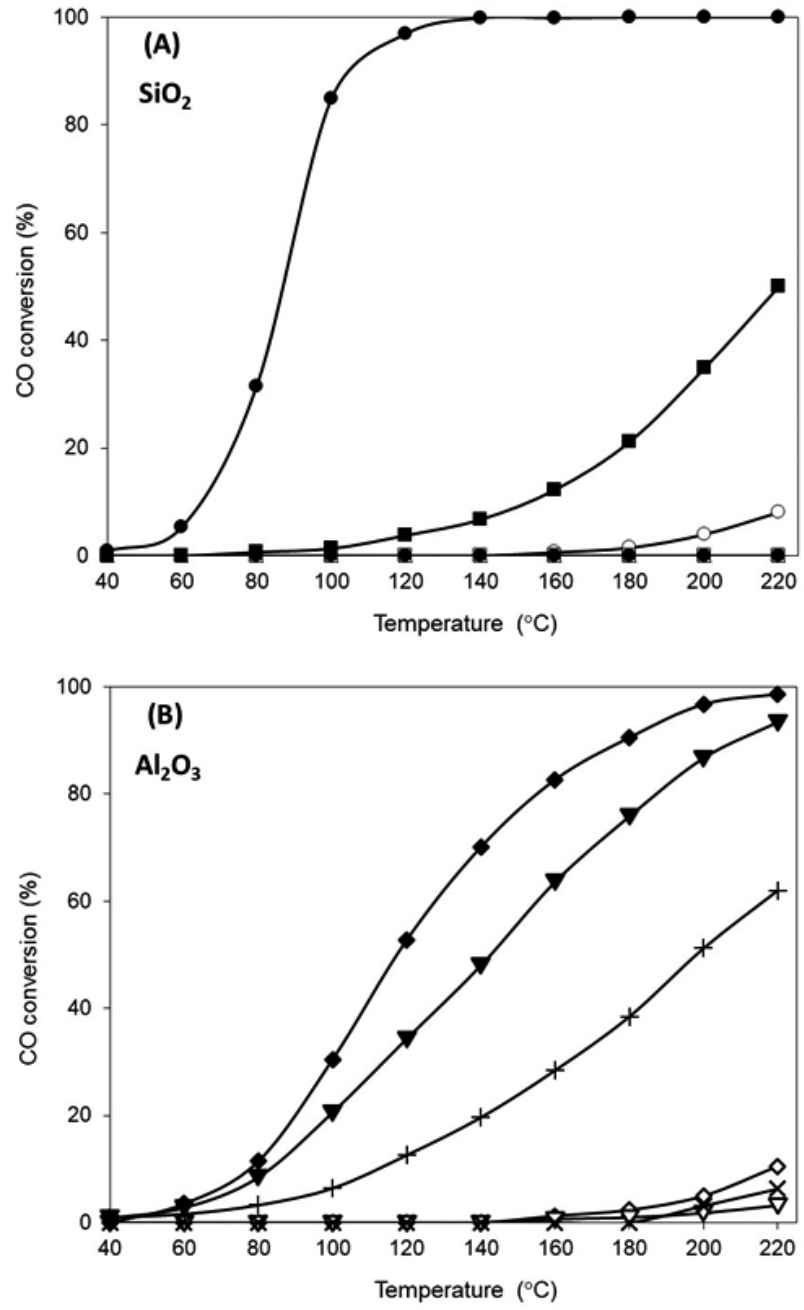

Figure 4: Activity in $\mathrm{CO}$ oxidation of monometallic $(\mathrm{Cu})$ and bimetallic $(\mathrm{CuCe})$ catalysts. (A) Supported on $\mathrm{SiO}_{2}:($ o) $\mathrm{Cu} / \mathrm{Si}-500 ;(\square) \mathrm{Cu} / \mathrm{Si}-700 ;(\Delta) \mathrm{Cu} /$ Si-900; (•) CuCe/Si-500; (ロ) CuCe/Si-700; ( $\mathbf{\Lambda}) \mathrm{CuCe} / \mathrm{Si}-900 ;$ (B) Supported on $\mathrm{Al}_{2} \mathrm{O}_{3}:(\diamond) \mathrm{Cu} / \mathrm{Al}-500 ;(\nabla) \mathrm{Cu} / \mathrm{Al}-700 ;(\mathrm{X}) \mathrm{Cu} / \mathrm{Al}-900 ;(\bullet) \mathrm{CuCe} / \mathrm{Al}-500$; ( $)$ CuCe/Al-700; (+) CuCe/Al-900.

What is most interesting, however, is that calcination at high temperatures, even though it decreases the activity of the bimetallic catalysts supported on $\mathrm{Al}_{2} \mathrm{O}$, it does so in a smaller proportion than when they are supported on silica. In effect, when calcining at $900{ }^{\circ} \mathrm{C}$, the $\mathrm{CuCe} / \mathrm{Si}-900$ catalyst is completely inactive, while the $\mathrm{CuCe} / \mathrm{Al}-900$ catalyst shows considerable activity in the oxidation of $\mathrm{CO}$, achieving $60 \%$ conversion at $220{ }^{\circ} \mathrm{C}$. This greater activity must be associated with a greater stability of the $\mathrm{Cu}-\mathrm{CeO}_{2}$ interface on alumina than on silica. Indeed, the XRD experiments show that the $\mathrm{CeO}_{2}$ particles are less sintered on alumina than on silica, increasing in a somewhat pronounced way their size, as reported in Table 1. At the same time, the XRD and UV-vis DRS analyses do not detect the appearance of bulk $\mathrm{CuO}$ on alumina, indicating that the sintering of $\mathrm{Cu}$ to form bulk $\mathrm{CuO}$ is also less on alumina than on silica. Clearly, the inert character of silica favors the sintering of the $\mathrm{Cu}$ species and $\mathrm{CeO}_{2}$ particles and their segregation on the surface of the silica as the temperature is increased, decreasing strongly the concentration of sites on the interface. Supporting on alumina, the interaction with the support inhibits the growth and separation of the $\mathrm{Cu}$ species and $\mathrm{CeO}_{2}$ particles, allowing interfacial $\mathrm{Cu}-\mathrm{CeO}_{2}$ sites even after calcining at $900{ }^{\circ} \mathrm{C}$.

The results of the activity of the different monometallic and bimetallic catalysts supported on $\mathrm{SiO}_{2}$ and $\mathrm{Al}_{2} \mathrm{O}_{3}$ in the decomposition of $\mathrm{N}_{2} \mathrm{O}$ are shown in Figures $5 \mathrm{~A}$ and $5 \mathrm{~B}$, respectively.

Figure $5 \mathrm{~A}$ shows all the monometallic $\mathrm{Cu}$ catalysts supported on silica are inactive in the decomposition of $\mathrm{N}_{2} \mathrm{O}$. As expected, the addition of $\mathrm{CeO}_{2}$ improves noticeably the activity of the catalysts, achieving more than $80 \%$ conversion with the catalyst calcined at $500{ }^{\circ} \mathrm{C}$. This result shows clearly that the $\mathrm{Cu}-\mathrm{CeO}$ interface is responsible for the catalytic activity of these systems, as already reported in the literature [13-16]. If the $\mathrm{Cu}-\mathrm{CeO}_{2}$ interface is responsible for the catalyst's activity, it would be expected that the $\mathrm{N}_{2} \mathrm{O}$ decomposition activity should follow the same trend as the oxidation activity of $\mathrm{CO}$ with $\mathrm{O}_{2}$. In effect, this is what happens. With calcining at $700{ }^{\circ} \mathrm{C}$, the activity decreases substantially, and it is practically nil after calcining at 900 ${ }^{\circ} \mathrm{C}$, following the same trend as in the $\mathrm{CO}$ oxidation reaction. The decrease of the interfacial sites due to the sintering and segregation of $\mathrm{Cu}$ species and $\mathrm{CeO}_{2}$ particles on the surface of the silica account for the behavior in the decomposition of $\mathrm{N}_{2} \mathrm{O}$

When alumina is used for support, the behavior of the monometallic $\mathrm{Cu}$ catalysts is very different from that observed on $\mathrm{Cu}$ supported on silica. Figure $5 \mathrm{~B}$ shows that the monometallic $\mathrm{Cu}$ catalysts have a noticeable catalytic activity in the decomposition of $\mathrm{N}_{2} \mathrm{O}$, which is consistent with other studies [36, 48], achieving $63.5 \%$ conversion at $600{ }^{\circ} \mathrm{C}$ in the case of the catalyst calcined at $500{ }^{\circ} \mathrm{C}$. Increasing the calcination temperature to $700{ }^{\circ} \mathrm{C}$, reduces the activity at $600{ }^{\circ} \mathrm{C}$ to $48.1 \%$, and calcining at $900{ }^{\circ} \mathrm{C}$ increases it slightly, reaching $51.8 \%$ conversion. This behavior coincides with what is seen in the TPR experiments, where the ease of reduction increases by calcining between 700 and $900{ }^{\circ} \mathrm{C}$. On the other hand, the addition of $\mathrm{CeO}_{2}$ produces an increase in the activity of all the catalysts supported on alumina. This activity increase, due to adding $\mathrm{CeO}_{2}$, is not as important as that observed when using $\mathrm{SiO}_{2}$ for support, due to the activity of the monometallic $\mathrm{Cu}$ catalysts supported on alumina. The bimetallic catalyst calcined at $500{ }^{\circ} \mathrm{C}$ achieves $95.4 \%$ conversion at $600{ }^{\circ} \mathrm{C}$, which is significantly greater than the $63.5 \%$ achieved by the monometallic catalyst.
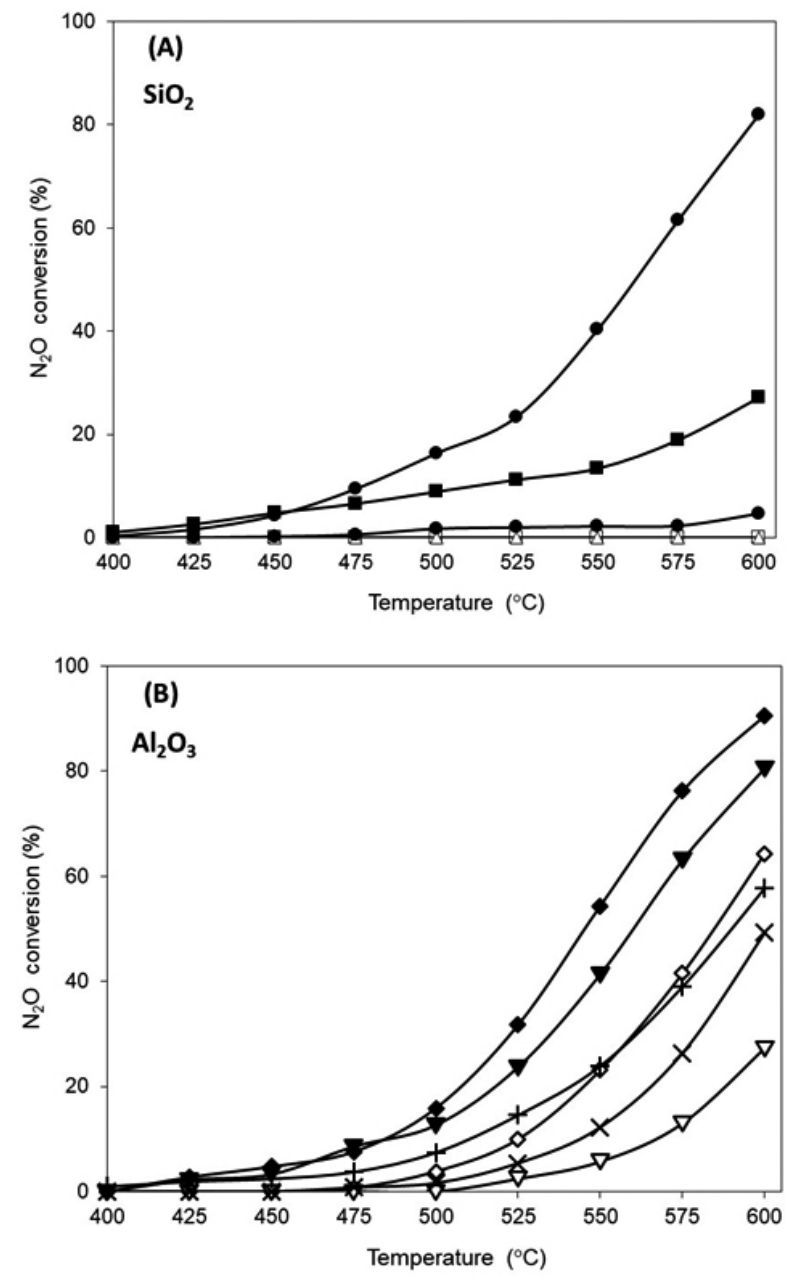

Figure 5: Activity in $\mathrm{N}_{2} \mathrm{O}$ decomposition of monometallic $(\mathrm{Cu})$ and bimetallic $(\mathrm{CuCe})$ catalysts. (A) Supported on $\mathrm{SiO}_{2}$ : (o) $\mathrm{Cu} / \mathrm{Si}-500$; $(\square) \mathrm{Cu} / \mathrm{Si}-$

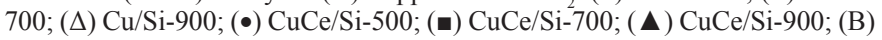
Supported on $\mathrm{Al}_{2} \mathrm{O}_{3}:(\diamond) \mathrm{Cu} / \mathrm{Al}-500 ;(\nabla) \mathrm{Cu} / \mathrm{Al}-700 ;(\mathrm{X}) \mathrm{Cu} / \mathrm{Al}-900 ;(\diamond) \mathrm{CuCe} /$ $\mathrm{Al}-500 ;(\boldsymbol{\nabla}) \mathrm{CuCe} / \mathrm{Al}-700 ;(+) \mathrm{CuCe} / \mathrm{Al}-900$. 
When the bimetallic $\mathrm{Cu}-\mathrm{Ce}$ catalyst supported on alumina is calcined at $700{ }^{\circ} \mathrm{C}$ (Figure 5B), the activity at $600{ }^{\circ} \mathrm{C}$ drops slightly to $86.5 \%$. This is significantly higher than the $48.1 \%$ conversion activity of the monometallic catalyst calcined at the same temperature, demonstrating the importance of the activity of the $\mathrm{Cu}-\mathrm{CeO}_{2}$ interface. Increasing calcination temperature at $900{ }^{\circ} \mathrm{C}$, the activity of the bimetallic $\mathrm{Cu}-\mathrm{Ce}$ catalyst drops to $61.1 \%$, and the difference with respect to the conversion of the monometallic $\mathrm{Cu}$ catalyst (48.1\%) decreases. It is evident that calcination at $900{ }^{\circ} \mathrm{C}$ causes a decrease of the concentration of interfacial sites, but their concentration is still sufficiently high to keep an activity greater than that of the monometallic catalyst calcined at the same temperature.

In short, the results of the $\mathrm{N}_{2} \mathrm{O}$ decomposition activity confirm that the sites of the $\mathrm{Cu}-\mathrm{CeO}_{2}$ interface are highly active in this reaction and the stability of this interface is better when it is supported on alumina rather than on silica. Therefore, the characterization of the catalysts as well as their activity in the oxidation of $\mathrm{CO}$ with $\mathrm{O}_{2}$ and the decomposition of $\mathrm{N}_{2} \mathrm{O}$ reactions show that the thermal stability of the $\mathrm{Cu}-\mathrm{CeO}_{2}$ interface is better when using alumina for support, in the calcination temperature range of $500{ }^{\circ} \mathrm{C}$ to $900{ }^{\circ} \mathrm{C}$ used in the present study.

\section{4.- CONCLUSIONS}

The results clearly show that the support has an important influence on the formation and stability of the $\mathrm{Cu}-\mathrm{CeO}_{2}$ interface. Although the formation of interfacial $\mathrm{Cu}-\mathrm{CeO}_{2}$ sites is favored in the catalysts calcined at $500{ }^{\circ} \mathrm{C}$ using silica for support, the thermal stability of the interface is low. Calcination at $900{ }^{\circ} \mathrm{C}$ causes the growth of the $\mathrm{Cu}$ species and $\mathrm{CeO}_{2}$ particles, and their complete separation on the surface of the silica. The disappearance of the $\mathrm{Cu}$ $\mathrm{CeO}_{2}$ interfacial sites is responsible for the catalytic activity in the oxidation of $\mathrm{CO}$ and the decomposition of $\mathrm{N}_{2} \mathrm{O}$. On the one hand, the inert character of silica improves the interaction between $\mathrm{Cu}$ and $\mathrm{CeO}_{2}$, but on the other hand, it favors the sintering of these species as the calcination temperature is increased.

In contrast, if $\mathrm{Al}_{2} \mathrm{O}_{3}$ is used for support, the bimetallic catalysts maintain an important activity in both reactions when they are calcined at $900{ }^{\circ} \mathrm{C}$, due to a greater stability of the $\mathrm{Cu}-\mathrm{CeO}$ interface. This stability is attributed to the fact that the interaction of the $\mathrm{Cu}$ and $\mathrm{Ce}$ species with the support decreases the sintering of the $\mathrm{Cu}$ and $\mathrm{CeO}_{2}$ particles, such that even after calcining at $900{ }^{\circ} \mathrm{C}$, some interfacial $\mathrm{Cu}-\mathrm{CeO}_{2}$ sites still exist on the surface of the alumina, generating an important catalytic activity in both reactions.

\section{ACKNOWLEDGEMENTS}

The authors acknowledge gratefully the financial support of this work under Fondecyt project 1161227.

\section{REFERENCES}

1. Liu W, Flytzani-Stephanopoulos M (1995) J. Catal. 153: 304-316

2. Kundakovic L, M. Flytzani-Stephanopoulos M (1998) J. Catalysis 179: 203-221

3. Li Y, Fu Q, Flytzani-Stephanopoulos M (2000) Applied Catalysis B 27: $179-191$

4. Kundakovic L, Flytzani-Stephanopoulos M (1998) Applied Catalysis A 171: 13-29

5. Liu Y, Fu Q, Flytzani-Stephanopoulos M (2004) Catalysis Today 93: 241246

6. Madier Y, Descorme C, Le Govic A, Duprez D (1999) J. Phys. Chem. B 103: 10999-11006

7. Martinez-Arias A, Fernandez-Garcia M, Galvez O, Coronado J, Anderson J, Conesa J, Soria J, Munuera, G (2000) J. Catal. 195: 207-216

8. Yao S, Mudiyanselage $\mathrm{K}, \mathrm{Xu}$ W, Johnston-Peck A, Hanson J, Wu T, Stacchiola D, Rodriguez J, Zhao H, Beyer K, Chapman K, Chupas P, Martinez-Arias A, Si R, Bolin T, Liu W, Senanayake S (2014) ACS Catalysis 4: 1650-1661

9. Wang W, Du P, Zou S, He H, Wang R, Jin Z, Shi S, Huang Y, Si R, Song Q, Jia C, Yan C (2015) ACS Catalysis 5: 2088-2099

10. Davo-Quiñonero, Navlani-Garcia M, Lozano-Castello D, Bueno-Lopez A, Anderson J (2016) ACS Catalysis 6: 1723-1731

11. Benedetto A, Landi G, Lisi L (2017) International Journal of Hydrogen Energy 42: 12262-12275

12. Wang X, Rodriguez J, Hanson J, Gamarra D, Martinez-Arias A, FernandezGarcia M (2006) J. Phys. Chem. B 110: 428-434
13. Adamski A, Zajac W, Zasada F, Sojka Z (2012) Catalysis Today 191: 129-133

14. Zhou H, Huang Z, Sun C, Qin F, Xiong D, Shen W, Xu H (2012) Applied Catalysis B 125: 492-498

15. Zabilskiy M, Erjavec B, Djinovic P, Pintar A (2014) Chemical Engineering Journal 254: 153-162

16. Zabilskiy M, Djinovic P, Erjavec B, Drazic G, Pintar A (2015) Applied Catalysis B 163: 113-122

17. Hevia M, Pérez-Ramírez J (2008) Applied Catalysis B 77: 248-254

18. Gunawardana P, Lee H, Kim D (2009) International Journal of Hydrogen Energy 34: 1336-1341

19. Djinovic P, Levec J, Pintar A (2008) Catalysis Today 138: 222-227

20. Pintar A, Batista J, Hocevar S (2007) Journal of Colloid and Interface Science 307: 145-157

21. Djinovic P, Batista J, Pintar A (2008) Applied Catalysis A 347: 23-33

22. Pradhan S, Reddy A, Devi R, Chilkuri S (2009) Catalysis Today 141: 72 76

23. Sun Y, Hla S, Duffy G, Cousins A, French D, Morphet L, Edwards J, Roberts D (2010) Catalysis Communications 12: 304-309

24. Schwarz J, Contescu C, Contescu A, Chem. Rev. (1995) 95: 477-510

25. Aguila G, Gracia F, Araya P (2008) Applied Catalysis A 343: 16-24

26. Aguila G, Guerrero S, Araya P (2013) Applied Catalysis A 462: 56-63

27. Friedman R, Freeman J, Lytle W (1978) Journal of Catalysis 55: 10-28

28. Strohmeier B, Leyden D, Field R, Hercules D (1985) Journal of Catalysis 94: 514-530

29. Cheektamarla P, Epling W, Lane A (2005) Journal of Power Sources 147 178-183

30. Luo M, Fang P, He M, Xie Y (2005) Journal of Molecular Catalysis A Chemical 239: 243-248

31. Liu Z, Amiridis A, Chen Y (2005) J. Phys. Chem. B 109: 1251-1255

32. Zhou R, Jiang X, Mao J, Zheng X (1997) Applied Catalysis A 162: 213 222

33. Ma Z, Yang C, Wei W, Li W, Sun Y (2005) J. Mol. Catal. A: Chem. 231: $75-81$

34. Shan W, Shen W, Li C, (2003) Chem. Mater. 15: 4761-4767

35. Dow W, Wang Y, Huang T (1996) Journal of Catalysis 160: 155-170

36. Yao K, Jaenicke S, Lin J, Tan K (1998) Applied Catalysis B 16: 291-301

37. Xiaoyuan J, Liping L, Yingxu C, Xiaoming Z (2003) Journal of Molecular Catalysis A 197: 193-205

38. Severino F, Brito J, Carias O, Laine J (1986) Journal of Catalysis 102: 172-179

39. Yahiro H, Nakaya K, Yamamoto T, Saiki K, Yamaura H (2006) Catalysis Communications 7: 228-231

40. Dumas J, Geron C, Kribii A, Barbier J (1989) Applied Catalysis 47: L9L15

41. Sato S, Iijima M, Nakyama T, Sodesawa T, Nozaki F (1997) Journal of Catalysis 169: 447-454

42. Gang L, Grondelle J, Anderson B, van Santen R (1999) Journal of Catalysis 186: 100-109

43. Praliaud H, Mikhailenko S, Chajar Z, Primet M (1998) Applied Catalysis B 16: 359-374

44. Shimokawabe M, Takesawa N, Kobayashi H (1982) Applied Catalysis 2 379-387

45. Martinez-Arias A, Fernandez-Garcia M, Salamanca L, Valenzuela R, Conesa J, Soria J (2000) J. Phys. Chem. B 104: 4038-4046

46. Hu H, Dong L, Shen M, Liu D, Wang J, Ding W, Chen Y (2001) Applied Catalysis B 31: 61-69

47. S. Velu S, K. Susuki, K M. Okazaki M, M. Kapoor M, T. Osaki T, F. Ohashi F (2000) Journal of Catalysis 194: 373-384

48. Dandekar A, Vannice M (1999) Applied Catalysis B 22: 179-200 